\title{
Moult activity-related spawning success in the Mediterranean deep-water shrimp Aristeus antennatus (Decapoda: Dendrobranchiata)
}

\author{
M. Demestre* \\ Institut de Ciències del Mar, Passeig Joan de Borbó s/n, E-08039 Barcelona, Spain
}

\begin{abstract}
The relationship between mating, spawning and moult cycles of Aristeus antennatus (Risso, 1816) (Dendrobranchiata: Aristeidae) was analysed for 4 yr as a determinant of reproductive strategies. Field specimens were obtained from an exploited population of the Catalan coast, Spain (northwestern Mediterranean). It was found that females showed a marked reproductive seasonality while males showed potential for year-round reproductive activity. Although several layings occurred during an annual reproductive period, there was only 1 per instar. A. antennatus had an indeterminate growth pattern. Moulting activity of both sexes was present throughout the year but increased in females during the reproductive period. In addition, during vitellogenesis the moult cycle of females was not prolonged during intermoult stages or during initial premoult stages. This finding indicates that the high moult activity of females during the seasonal reproductive cycle must be displayed in order to obtain an optimum level of fertilization. Furthermore, results suggest that during the spawning period, moulting phenomena are most closely linked to reproduction rather than to growth. Finally, it is proposed that intraspecific biotic factors rather than environmental and energetic ones appear to be a key for determining the reproductive success of $A$. antennatus.
\end{abstract}

KEY WORDS: Crustacea $\cdot$ Reproductive success $\cdot$ Moulting $\cdot$ Spawning $\cdot$ Environmental variables

\section{INTRODUCTION}

Diverse reproductive strategies occur in decapod crustaceans, with the object of synchronising the spawning period with the moult and phasing it in with seasonal fluctuations of the environment (Sastry 1983. Adiyodi 1985, Conan 1985, Hartnoll 1985). The mechanisms have been investigated in both field (Webster 1982, Abelló 1989, Havens \& McConaugha 1990) and laboratory studies (Carlisle 1957, Cheung 1969, MacDiarmid 1989, Bouchon 1991) mainly for Pleocyemata species, which brood their eggs. However, few studies have been performed on broadcast spawning species of the Dendrobranchiata suborder.

The existing literature on studies of reproduction and moulting in Dendrobranchiata shows the exis-

\footnotetext{
·E-mail: montse@masagran.icm.csis.es
}

tence of 2 different strategies regarding the synchronism between the moult cycle and the spawning season. Species exist in which vitellogenesis and spawning take place between 2 successive moults (Penn 1980, Crocos \& Kerr 1983, Shlagman et al. 1986), whilst others carry out more than 1 spawning between 2 successive moults, where the intermoult period can last for several months (Martosubroto 1974, Emmerson 1980, Aquacop 1983, Anderson et al. 1985). In both cases the vitellogenetic females are in intermoult or an initial premoult stage, which means that the moult activity stops or slows down (Scheer 1960). Similar studies on Aristeus antennatus and other Mediterranean Dendrobranchiata species appear not to have been carried out.

The current study shows that, during the spawning period, females of Aristeus antennatus not only have activity during the moult cycle but also that this activity increases. Since $A$. antennatus does not follow the 
general trend of other Dendrobranchiata species, towards reproduction and moulting, an attempt was made to obtain estimates of seasonal reproduction, spawning period, moult cycle and possible causes of their synchronism, and to relate these to environmental variables in order to determine the reproductive success of $A$. antennatus. It is further suggested that the most realistic temporal synchronism for the observed mating, spawning, and moulting phenomena is to maximise the reproductive effort.

\section{MATERIAL AND METHODS}

Sampling data. Samples of 'gamba' shrimp Aristeus antennatus were obtained from catches of commercial bottom trawls ( $36 \mathrm{~mm}$ mesh size, $18 \mathrm{~mm}$ side) during the day, in order to restrict the sampling to the main boundary of this species which is located near the bottom of the middle slope at daylight (Cartes \& Sardà 1993). Specimens were collected along the Catalan coast, Spain (northwestern Mediterranean) in 1984, 1985, 1986 and 1989. The area sampled consisted of muddy bottoms in submarine canyons on the middle slope between 400 and $800 \mathrm{~m}$ (Fig. 1). Sex, carapace length ( $\mathrm{CL} \mathrm{mm}$, from the right orbital margin to the mid posterior edge of the carapace), weight (W), gonad wet weight (GW), presence or absence of spermatophore in the thelycum of the females, sexual stages and moult stages were determined in the laboratory for 7177 individuals (5044 females and 2133 males).

Reproduction period. To determine the reproductive cycle both seasonality of gonad maturation and the spawning period were considered. To study seasonality different stages of maturation of the ovary and

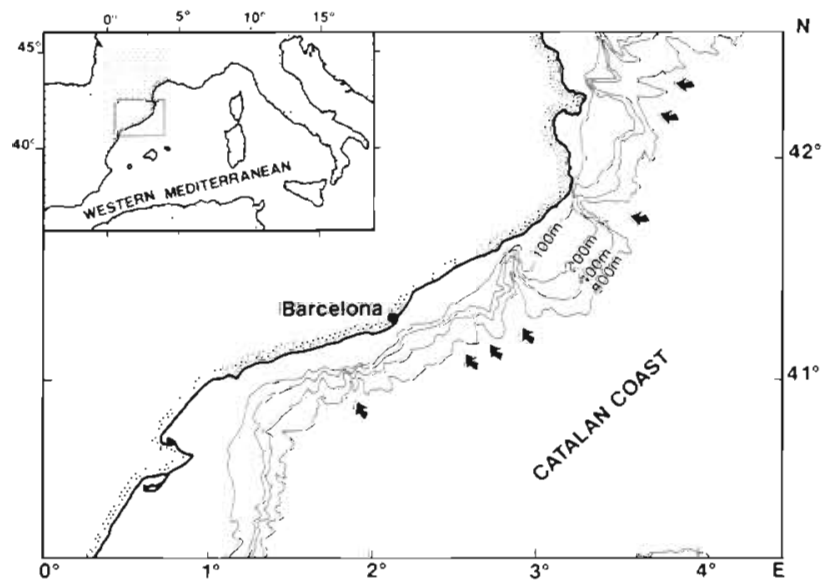

Fig. 1. Aristeus antennatus. Study area showing fishing grounds (arrows) off the Catalan coast. Depths also shown testes (maturation stages are described in Demestre \& Fortuño 1992), gonadosomatic index (GSI: GW/W $\times$ $100)$ and presence or absence of spermatophores in the thelycum of the females were used. The spawning period was determined by estimation of the monthly percentage of ripe oocytes, which show cortical specialisations (CS), as indicators both of the most advanced stage of vitellogenesis (Orsi Relini \& Semeria 1983, Yano 1988, Demestre \& Fortuño 1992) and of an imminent spawning (Anderson et al. 1984).

Moulting activity. The moult cycle was studied by analysing the evolution of 6 different moult stages (according to Skinner 1985 and Sardà \& Demestre 1985) by microscopic observations of integumental changes of the pleopod setae (Table 1). Other indicative criteria of a recent moulting, such as the presence of 'soft' individuals (Anderson et al. 1985) or the presence of branchiostegites still attached to the carapace (MacDiarmid 1989) were not used due to the scarcity of recently moulted specimens in the samples. In addition, to test the degree of synchronisation between moulting and spawning processes, the relative duration of the moult cycle was estimated, assuming that the number of individuals at each moulting stage was directly proportional to its duration (Sardà \& Demestre 1985). Only mature females $\mathrm{CL}>26 \mathrm{~mm}$ (Demestre \& Martín 1993) were used to determine the moult period.

Table 1. Aristeus antennatus. Description of shrmp moult stages (from Sardà \& Demestre 1985)

\begin{tabular}{|c|c|}
\hline Stage & Description \\
\hline $\mathrm{C}$ & $\begin{array}{l}\text { Intermoult. State of rest between } 2 \text { ecdyses or } \\
\text { exuviations. The central nerve of the setae of the } \\
\text { pleopod is clearly separated from the cuticle }\end{array}$ \\
\hline $\mathrm{D}_{0}$ & $\begin{array}{l}\text { Start of proecdysis. The separation begins } \\
\text { between the epithelium and the cuticle, espe- } \\
\text { cially in the lower part of the setae. The latter } \\
\text { shows no apparent appreciative changes }\end{array}$ \\
\hline$D_{1}$ & $\begin{array}{l}\text { Proecdysis. The formation of the new setae } \\
\text { begins, by means of the invagination of the } \\
\text { epidermis in the matnx of the pleopod. New } \\
\text { cuticular layers are noticeable }\end{array}$ \\
\hline $\mathrm{D}_{2}$ & $\begin{array}{l}\text { Advanced proecdysis. Formation of the cuticular } \\
\text { structure is completed. Invaginations reach their } \\
\text { maximum depth. The formation of the new setae } \\
\text { and pleopod is complete. Within a short time the } \\
\text { ecdysis will be formed }\end{array}$ \\
\hline A & $\begin{array}{l}\text { Immediate postecdysis. Well-developed setae } \\
\text { filled with a uniform matrix without differenti- } \\
\text { ated structures }\end{array}$ \\
\hline B & $\begin{array}{l}\text { Advanced postecdysis. The matrix starts to come } \\
\text { away from the walls. Beginning of central } \\
\text { nervation }\end{array}$ \\
\hline
\end{tabular}




\section{RESULTS}

\section{Reproductive activity and spawning period}

The functional activity of the ovary was evident for almost 6 months of the year from the end of April to the beginning of October (Table 2). In early May all stages of maturation appeared for the first time, with the resting stage (II) showing the highest percentage. In late May the situation was reversed, with previtellogenetic (III) and vitellogenetic stages (IV-VI) showing greater dominance. The incidence of oocytes in the secondary vitellogenesis phase and with CS (stages V, VI) was at a maximum in late May, June, July and August, reaching percentages greater than $50 \%$. Similarly, the highest values of spermatophore frequency occurring in the thelycum of females (Table 2) were obtained consistently between the months of May and September ( 80 to $100 \%$ ), when all the females displayed ripe ovaries (stages V-VI). On the other hand, between November and March the presence of spermatophores was practically nil (less than 10\%). Thus, the spawning period of 'gamba' shrimp began basically in late May and was prolonged, at least, for 4 mo until late September. All these data indicate a high potential spawning capacity in the population within the same annual reproduction period, and show that females of Aristeus antennatus may be able to carry out at least 1 spawning per month during June, July and August.

Although mature males appeared in all the months of the year, it was at the end of the spring and during the summer, between March and August, that the greatest reproductive activity was observed (Table 3).

The monthly evolution of GSI mean values in females throughout 1984 and 1985 (Fig. 2) showed that
Table 3. Aristeus antennatus, males. Monthly mean percentages of maturation during $1984,1985,1986,1989 . \mathrm{N}$ : number of males

\begin{tabular}{|c|c|c|c|}
\hline \multirow[t]{2}{*}{ Date } & \multicolumn{2}{|c|}{ Maturation (\%) } & \multirow[t]{2}{*}{$N$} \\
\hline & Immature & Mature & \\
\hline Jan & 27.2 & 72.8 & 191 \\
\hline Feb & 22.3 & 77.7 & 179 \\
\hline Mar & 8.1 & 91.9 & 172 \\
\hline Apr & 8.2 & 91.8 & 182 \\
\hline May & 10.4 & 89.6 & 154 \\
\hline Jun & 3.8 & 96.2 & 105 \\
\hline Jul & 9.7 & 90.3 & 248 \\
\hline Aug & 8.3 & 91.7 & 264 \\
\hline Sep & 20.4 & 79.6 & 216 \\
\hline Oct & 21.6 & 78.4 & 245 \\
\hline Nov & 54.1 & 45.9 & 109 \\
\hline Dec & 16.2 & 83.8 & 68 \\
\hline
\end{tabular}

the maximum values occurred between June and August inclusively. In the months in which the highest values of GSI were observed, practically $100 \%$ of the adult females in the population were found with developed ovaries. In males (Fig. 2), despite the monthly variation of the GSI value not being very pronounced, increased activity began in May and continued until August and September.

\section{Moult cycle and frequency of spawning}

To analyse the seasonality of the moult cycle the monthly percentages of premoult $D_{1}$ and $D_{2}$, and postmoult $A$ and $B$ stages (stages close to the ecdysis) were calculated during the period 1984-1986 (Fig. 3). Moult seasonality was evident in females with a high per-

Table 2. Aristeus antennatus, females. Monthly mean percentages of maturity stages and presence of spermatophores in the thelycum during 1984,1985, 1986 and 1989. N: number of females

\begin{tabular}{|c|c|c|c|c|c|c|c|c|c|}
\hline \multirow[t]{2}{*}{ Date } & \multirow[b]{2}{*}{ I } & \multicolumn{4}{|c|}{ Maturation stages $(\%)$} & \multirow{2}{*}{\multicolumn{2}{|c|}{$N$}} & \multicolumn{2}{|c|}{ Spermatophore } \\
\hline & & II & III & IV & V & & & $\%$ & $\mathrm{~N}$ \\
\hline Jan & 25.8 & 74.2 & 0 & 0 & 0 & 0 & 473 & 2.0 & 100 \\
\hline Feb & 17.3 & 82.7 & 0 & 0 & 0 & 0 & 416 & 0.7 & 149 \\
\hline Mar & 18.8 & 81.2 & 0 & 0 & 0 & 0 & 218 & 27.4 & 113 \\
\hline Apr & 9.6 & 88.2 & 2.2 & 0 & 0 & 0 & 323 & 56.3 & 214 \\
\hline May (early) & 14.5 & 41.1 & 14.5 & 13 & 10.6 & 6.3 & 207 & 76.0 & 93 \\
\hline May (late) & 5.4 & 9.5 & 16.3 & 18.6 & 28.5 & 21.7 & 221 & 85.6 & 118 \\
\hline Jun & 3.7 & 1.5 & 8.2 & 21.8 & 19.8 & 45 & 404 & 94.3 & 105 \\
\hline Jul & 0.5 & 0.5 & 7.6 & 19.9 & 31.2 & 40.3 & 659 & 100.0 & 206 \\
\hline Aug & 14.9 & 5.6 & 10.2 & 20.1 & 30.7 & 18.5 & 596 & 100.0 & 102 \\
\hline Sep (early) & 13.1 & 32.7 & 7.9 & 16.1 & 13.9 & 16.3 & 367 & 90.2 & 92 \\
\hline Sep (late) & 18 & 69.1 & 2.3 & 2.3 & 1.8 & 6.5 & 217 & - & - \\
\hline Oct & 31.9 & 67.7 & 0 & 0.2 & 0 & 0.2 & 455 & 19.8 & 86 \\
\hline Nov & 25.4 & 74.6 & 0 & 0 & 0 & 0 & 260 & 6.7 & 75 \\
\hline Dec & 11.4 & 88.6 & 0 & 0 & 0 & 0 & 228 & 8.6 & 70 \\
\hline
\end{tabular}




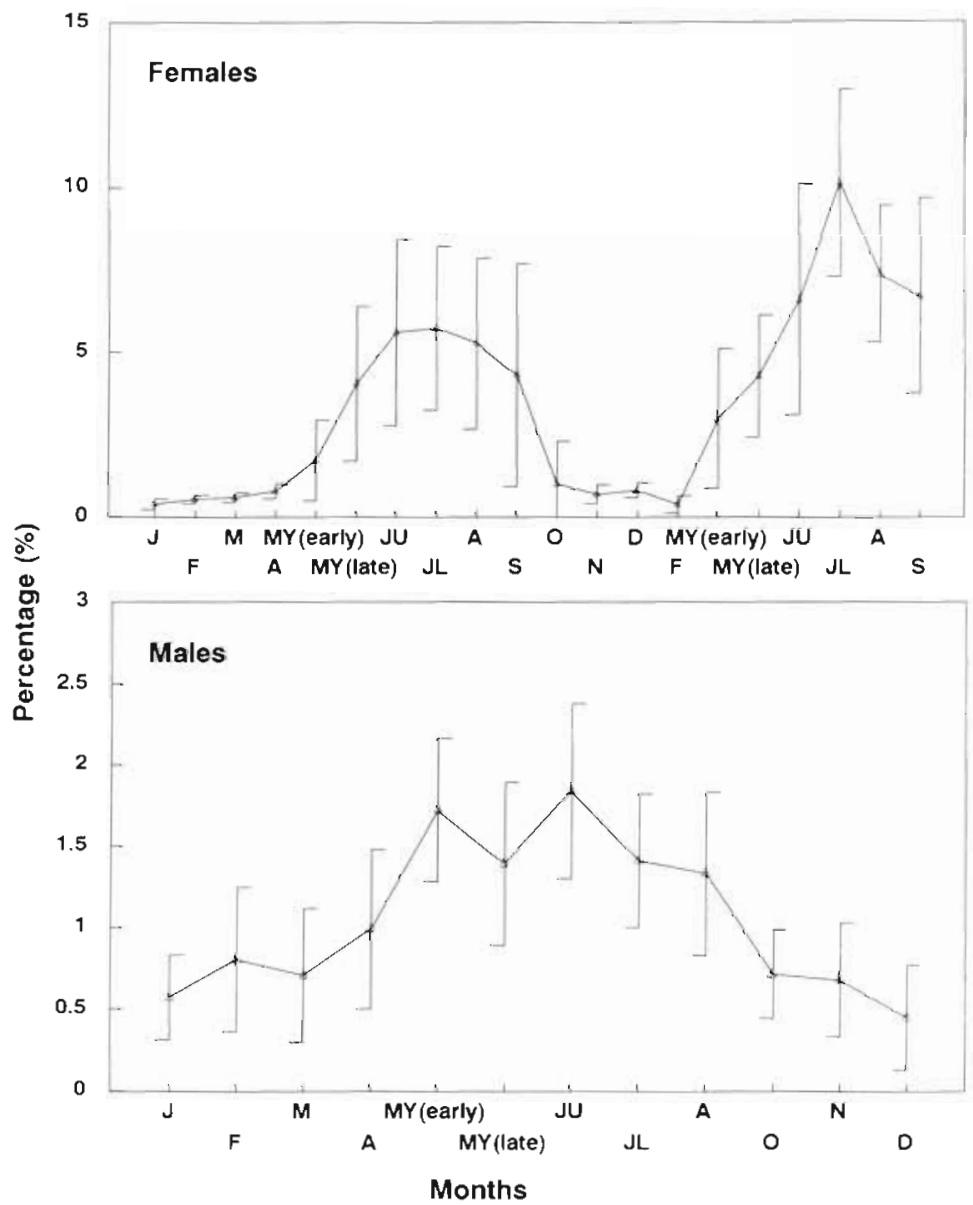

Fig. 2. Aristeus antennatus. Mean and coefficient of variation of monthly gonadosomatic index (GSI) values of females and males during $1984-1985$ centage of moult activity between early May and late September which reached values of over $60 \%$. During autumn and winter this percentage activity slowed down to around $40 \%$, but it is worth noting the high percentages of moulting in February and December (55.9 and $58.3 \%$ respectively), just when spawning activity has completely finished. As in females, the moult activity in the male population did not stop during the entire annual cycle, with values around or over $60 \%$ in February-March, June, September and November-December. The previous results of maturation, mating, spawning, and moulting activity displayed a temporal relationship (high percentage of spawning in late May, June, July and August, and high percentage of moulting activity between May and September) and a related dependence between both the effective reproductive success and moult frequency mechanisms.

To establish the possible intraspecific tactical pattern between spawning and moulting, the monthly percentage of moulting females at each ovary maturation stage was estimated (Table 4). From May to September, when females were basically in vitellogenetic stages (V-VI) (Table 2), there was clear evidence of moult activity. The annual mean of the percentage of moulting individuals during the pre-spawn (V) and spawn (VI) stages showed the highest values (59

Table 4. Aristeus antennatus. Monthly percentages (M\%) of moulting females and the annual mean percentage (Am\%) at each maturation stage during 1984-1986. N: number of females

\begin{tabular}{|c|c|c|c|c|c|c|c|c|c|c|c|c|}
\hline \multirow[t]{3}{*}{ Date } & \multicolumn{12}{|c|}{ Maturation stages } \\
\hline & \multicolumn{2}{|c|}{ I } & \multicolumn{2}{|c|}{ II } & \multicolumn{2}{|c|}{ III } & \multicolumn{2}{|c|}{ IV } & \multicolumn{2}{|c|}{$V^{d}$} & \multicolumn{2}{|c|}{$V I^{a}$} \\
\hline & $\mathrm{N}$ & $M \%$ & $N$ & $M \%$ & N & $M \%$ & $N$ & $M \%$ & N & $M \%$ & $N$ & $M \%$ \\
\hline $\operatorname{Jan}$ & 44 & 39 & 226 & 33 & 0 & - & 0 & - & 0 & - & 0 & - \\
\hline Feb & 46 & 48 & 116 & 33 & 0 & - & 0 & - & 0 & - & 0 & - \\
\hline Mar & 21 & 43 & 108 & 36 & 0 & - & 0 & - & 0 & - & 0 & - \\
\hline Apr & 30 & 50 & 89 & 36 & 0 & - & 0 & - & 0 & - & 0 & - \\
\hline May (early) & 4 & 25 & 83 & 53 & 6 & 50 & 0 & - & 0 & - & 0 & - \\
\hline May (late) & 40 & 67 & 57 & 65 & 30 & 67 & 29 & 45 & 39 & 51 & 42 & 40 \\
\hline Jun & 12 & 58 & 5 & 60 & 24 & 54 & 56 & 61 & 29 & 69 & 113 & 52 \\
\hline Jul & 0 & - & 0 & - & 37 & 41 & 66 & 36 & 112 & 59 & 164 & 57 \\
\hline Aug & 0 & - & 18 & 72 & 29 & 59 & 37 & 51 & 52 & 56 & 41 & 63 \\
\hline Sep & 35 & 80 & 74 & 55 & 12 & 33 & 24 & 75 & 11 & 73 & 7 & 29 \\
\hline $\mathrm{Oct}$ & 51 & 47 & 127 & 46 & 4 & 50 & 0 & - & 1 & 100 & 2 & 0 \\
\hline Nov & 26 & 42 & 77 & 33 & 0 & - & 0 & - & 0 & - & 0 & - \\
\hline Dec & 25 & 44 & 92 & 48 & 0 & - & 0 & - & 0 & - & 0 & - \\
\hline $\mathrm{Am} \%$ & & 51 & & 42 & & 52 & & 52 & & 59 & & 54 \\
\hline
\end{tabular}


and $54 \%$ respectively). In contrast, the resting stage (II) displayed the lowest value $(42 \%)$.

From the high proportion of the females found in moulting (values over $50 \%$; see Fig. 3) between late May and September, and the monthly periodicity of the sampling, the sequence of the monthly moult cycle in females showed that every month during the spawning period (the moult percentage at stages $V$ and VI was over $50 \%$; see Table 4), an ecdysis could potentially occur. In addition, the estimation of the relative length of time for each moulting stage (Table 5) showed that during the spawning period the duration of intermoult stages $\left(C\right.$ and $\left.D_{0}\right)$ was reduced. That is to say, the speed of moulting cycle increased.

On the other hand, both the high percentage (more than 50\%) of vitellogenetic oocytes (stages V and VI) and the presence of spermatophores throughout the spawning period (Table 2), indicated that females could possibly be in condition to spawn once a month within the same reproductive period.

\section{DISCUSSION}

\section{Maturation, mating and spawning}

The observed results reveal a marked seasonality in the ovarian maturation process of Aristeus antennatus with temporal synchronisation existing as much at the beginning of the season as at the end. The results obtained for males demonstrate that the reproductive activity of the adults occurs all year round. Displaying seasonality in maturation is not an isolated phenomenon within the Dendrobranchiata (Pérez Farfante

Table 5. Aristeus antennatus, females. Mean relative length of time, as a percentage (\%) for each moult stage (a) during a complete year, (b) from late May to September, during 1984-1986. N: number of females

\begin{tabular}{|c|c|c|c|c|c|c|}
\hline & \multicolumn{6}{|c|}{ Moult stage } \\
\hline & A & B & C & $\mathrm{D}_{0}$ & $D_{1}$ & $\mathrm{D}_{2}$ \\
\hline \multicolumn{7}{|c|}{ Complete year } \\
\hline $\mathrm{N}$ & 96 & 216 & 506 & 296 & 237 & 38 \\
\hline$\%$ & 6.92 & 15.49 & 36.46 & 21.33 & 17.08 & 2.74 \\
\hline \multicolumn{7}{|c|}{ Late May-September } \\
\hline$N$ & 46 & 96 & 162 & 106 & 103 & 14 \\
\hline$\%$ & 8.73 & 18.22 & 30.74 & 20.11 & 19.54 & 2.66 \\
\hline
\end{tabular}

1969, Orsi Relini \& Semeria 1983, Anderson et al. 1985. Arrobas \& Ribeiro Cascalho 1987). However, other Dendrobranchiata species show a maturation period that is more or less constant all year round, with maximum periods of activity (Cummings 1961, Shlagman et al. 1986, Ribeiro Cascalho \& Arrobas 1987). Furthermore, the rapid and massive rise of the percentage of females with spermatophores (in a month the difference increases from 50\% to $100 \%$ ) (Table 2) shows a high annual mating synchronisation in the 'gamba' shrimp population. Obviously, all the effort to obtain the maximum level of fertilisation must be concentrated between June and August. Since the results obtained for the spawning period showed that females of this shrimp could potentially carry out 1 spawning per month (i.e. at least 3 in the same reproductive season), the questions which arise are (1) whether the 3 spawnings would be carried out in the same intermoult period or whether each spawning would take place between 2 successive ecdysis, and (2) why moulting activity increases in females during vitellogenesis.

\section{Moult cycle and synchronism with spawning season}

In the published literature Dendrobranchiata always show the same pattern between reproduction and moult mechanisms: spawning occurs when stages of the premoult or instar period stop or slow down. However, females of Aristeus antennatus increase the activity of the moulting cycle during the spawning period. Due to this fact, the processes of mating, spawning and moulting have to be very closely 
related, in space and in time, in such a way that they all depend on each other

On the basis of the results of this study, it is probable that the strategy of the synchronism between reproduction and moult cycle of the Aristeus antennatus population could follow a sequence where the initial ovary development (throughout stage II to stage III) might trigger the onset of moulting, followed by mating and finally the last processes of vitellogenesis and spawning. It appears reasonable to think that this sequence, in agreement with the results shown, has to have taken place during a period of approximately 1 mo. Moreover, as is known from laboratory studies, on other species of penaeids, the spawning state and that of moulting are of very short duration, and in various published studies a period of between 10 and $50 \mathrm{~d}$ is given for the ovarian cycle (Pérez Farfante 1969, Aquacop 1983, Anderson et al. 1984, 1985).

This hypothesis implies that for each spawning, females need to have a new spermatophore available, because, since this species has an open thelycum without seminal receptacles, the mating and fecundation processes are totally external and the spermatophore is lost at each moult (Heldt 1938, Hudinaga 1942, Clark et al. 1984, Pérez Farfante 1987). On account of the high fecundity of Aristeus antennatus (more than 600000 oocytes ind. ${ }^{-1}$ are produced in each vitellogenesis; Orsi Relini \& Semeria 1983, Demestre 1990), it seems reasonable that each spawning female needs to have a large number of spermatozoa available. This could explain why females show stages approaching ecdysis during the spawning period. Furthermore, a deeper analysis of the results indicates that the relative time of the stages of intermoult is slightly longer than the other moulting stages (Table 5). During this time interval the carapace can quickly harden, although this species does not present a high calcification of the carapace (Sardà et al. 1989), at which point it is able to maintain a new spermatophore in the thelycum. $A$. antennatus have the so-called diecdysis moult cycle (see Carlisle 1957, Scheer 1960, Dall et al. 1990), i.e. regular ecdysis with a very short period of time between each one, which changes very quickly from the postmoult stages to a new premoult stage. This is supported by the low proportion of individuals in the field population at an advanced premoult and immediate postmoult stage during any one year (Table 5), and by the presence of very few 'soft' specimens in the catches of this shrimp (pers. obs.)

Although the existence of a strong antagonism between reproduction and growth has always been considered (Adiyodi 1985, Hartnoll 1985), in experimental laboratory studies with penaeids it has been possible to prove that they are not 2 incompatible phenomena, because they can occur simultaneously whenever adequate nutritional and environmental circumstances are present (Emmerson 1980, 1983). Due to the low level of calcification of this species, the energy demanded in the moult process and the condition of the hard shell in this species is not as rigorous as in other more calcified species. Furthermore, this shrimp shows a great trophic activity in a regular, constant and hardy way, thus being able to be considered as a random feeder (Cartes \& Sardá 1989). Demographic pressure on fecundity rather than energetic considerations is the primary selective mechanism influencing annual reproductive effort, as Hines (1982) observed in brachyuran crabs.

Considering that moulting has been described as a metabolic necessity independent from growth (Conan 1985), in Aristeus antennatus during the reproductive period the moults would not fulfil their mission related to growth but they would follow a reproductive strategy driven by an internal clock. In agreement with this argument, the high moult activity of females in February, early May, late September and December, which are months without spawning activity, reflects a massive moulting within the population, because it is a period during which females grow (unpubl. data). In contrast, between late May and early September the moulting activity has reproduction as the main aim. Penn (1980) working with Pennaeus latisulcatus and Crocos \& Kerr (1983) with Pennaeus merguiensis announced that moult frequency during the spawning season will be a governing factor in spawning frequency. Apparently, the 'gamba' shrimp grows indefinitely until it dies, just as Carlisle (1957) and Hartnoll (1985) suggested for prawns, shrimps and some lobsters, in which terminal anecdysis is unknown.

The discussion presented by Conan (1985) pointed out that there is no information as to whether the synchronisation between the moult and reproduction events is strictly hormonal and/or genetic interactions (Cheung 1969), or whether the synchronism is a local adaptation to external environmental factors, or whether the moult pattern would correspond entirely to the reproductive pattern. In this case, the scarcely fluctuating deep environment characterised by low levels of light intensity and since the habitat of Aristeus antennatus does not fluctuate with respect to the hydrography, temperature and salinity (Font 1987), to the photoperiod and to the diet (Cartes \& Sarda 1989), I suggest that it is probable that the mechanisms that cause reproduction are more characteristic of an autoregulation of the species ('internal clock') as for the characteristic moult cycle. For this spawning and moulting are closely related. Field and laboratory studies of periodicity and synchronicity of seasonal reproduction and moult activity of other deep Dendrobranchiata species close to $A$. antennatus, e.g Aristeus 
varidens, Aristeomorpha foliacea or Plesiopennaeus edwardsianus, would allow the present observations to be expanded and tested further.

Acknowledgements. I thank Dr F. Sarda for the determination of the different moult stages used in this study. I also thank the members of the Mediterranean Population Dynamics Group of the I.C.M. for their field assistance. In the latter regard, I am grateful to Dr C. Rodgers for the English version and for critical reading of the original manuscript. This work was partly supported by the Commission of the European Communities (D. G. XIV) and by grants from the CIRIT (Generalitat of Catalonia) and the 'Caixa de Barcelona'

\section{LITERATURE CITED}

Abelló P (1989) Reproduction and moulting in Liocarcinus depurator (Linnaeus, 1758) (Brachyura: Portunidae) in the northwestern Mediterranean Sea. Scientia mar 53: $127-134$

Adlyodi RG (1985) Reproduction and its control. In: Bliss DE, Mantel LH (eds) The biology of Crustacea, Vol 9, Integument, pigments and hormonal processes. Academic Press, New York, p 147-215

Anderson SL, Chang ES, Clark WH Jr (1984) Timing of postvitellogenic ovarian changes in the ridgeback prawn Sicyonia ingentus (Penaeidae) determined by ovarian biopsy. Aquaculture 42:257-271

Anderson SL, Clark WH Jr, Chang ES (1985) Multiple spawning and molt synchrony in a free spawning shrimp (SiCYonia ingentis: Penaeoidea). Biol Bull 168:377-394

Aquacop (1983) Constitution of broodstock, maturation, spawning and hatching systems for penaeid shrimps in the Centre Océanologique du Pacifique. In: McVey JP (ed) Handbook of mariculture, Vol 1, Crustacean aquaculture. CRC Press, Boca Raton, p 304-335

Arrobas I, Ribeiro Cascalho A (1987) On the biology and fishery of Aristeus antennatus (Risso, 1816) in the south Portuguese coast. Invest Pesq 51(Supl 1):233-243

Bouchon D (1991) Biological clock in seasonal reproductive cycle in the ditch shrimp Palaemonetes varians Leach. II. Ovarian state-dependent response to non-diel light-dark cycles. J exp mar Biol Ecol 146:13-26

Carlisle DB (1957) On the hormonal inhibition of moulting in decapod Crustacea. J mar biol Ass UK 36:291-307

Cartes JE, Sardà F (1989) Feeding ecology of the deep-water aristeid crustacean Aristeus antennatus. Mar Ecol Prog Ser 54:229-238

Cartes JE, Sarda F (1993) Zonation of deep-sea decapod fauna in the Catalan Sea (Western Mediterranean). Mar Ecol Prog Ser 94:27-34

Cheung TS (1969) The environmental and hormonal control of growth and reproduction in the adult female atone crab. Menippe mercenaria (Say). Biol Bull 136: $327-346$

Clark WH Jr, Yudin Al, Grffin FJ, Shigekawa K (1984) The control of gamete activation and fertilization in the marine Penaeidae, Sicyonia ingentis. In: Engels W, Clark WH Jr, Fischer A, Olive PJW, Went DF (eds) Advances in invertebrate reproduction, Vol 3. Elsevier, New York, p 459-472

Conan GY (1985) Periodicity and phasing molting. In: Wenner AM (ed) Crustacean issues, Vol 3, Factors in adult growth. AA Balkema, Rotterdam, p 73-99

Crocos PJ, Kerr JD (1983) Maturation and spawning of the banana prawn Penaeus merguiensis de Man (Crustacea:
Penaerdae) in the Gulf of Carpentaria, Australia. J exp mar Biol Ecol 69:37-59

Cummings WC (1961) Maturation and spawning of the pink shrimp. Penaeus duorarum Burkenroad. Trans Am Fish Soc 90:462-468

Dall W, Hill BJ, Rothlısberg PC, Sharples DJ (1990) The biology of the Penaeidae. In: Blaxter JHS, Southward AJ (eds) Advances in marine biology, Vol 27. Academic Press, New York, p $1-489$

Demestre M (1990) Biología pesquera de la gamba Aristeus antennatus (Risso, 1816) en el Mar Catalán. PhD thesis, Univ Barcelona

Demestre M. Fortuno JM. (1992) Reproduction of the deepwater shrimp Aristeus antennatus (Decapoda: Dendrobranchiata). Mar Ecol Prog Ser 84:41-51

Demestre M, Martín P (1993) Optimum exploitation of a demersal resource in the western Mediterranean: the fishery of the deep-water shrimp Aristeus antennatus (Risso, 1816). Scientia mar 57:175-182

Emmerson WD (1980) Induced maturation of prawn Penaeus indicus. Mar Ecol Prog Ser 2:121-131

Emmerson WD (1983) Maturation and growth of ablated and unablated Penaeus monodon Fabricius. Aquaculture 32: $235-241$

Font $J(1987)$ The path of the Levantine Intermediate Water to the Alboran Sea. Deep Sea Res 34:1745-1755

Hartnoll RG (1985) Growth, sexual maturity and reproductive output. In: Wenner AM (ed) Crustacean issues, Vol 3, Factors in adult growth. AA Balkema, Rotterdam, p 101-128

Havens KJ, MCConaugha JR (1990) Molting in the mature female blue crab, Callinectes sapidus Rathbun. Bull mar Sci $46: 37-47$

Heldt JH (1938) De l'appareil génital des Penaeidae. Relations morphologiques entre spermatophore, thelycum et petasma. Trav Stn Zool Wimereux 13:349-358

Hines AH (1982) Allometric constraits and variables of reproductive effort in brachyuran crabs. Mar Biol 69:309-320

Hudinaga M (1942) Reproduction, development and rearing of Penaeus japonicus Bate. Jap J Zool 10:305-393

MacDiarmid AB (1989) Moulting and reproduction of the spiny lobster Jasus edwardsii (Decapoda: Palinuridae) in northern New Zealand. Mar Biol 103:303-310

Martosubroto P (1974) Fecundity of pink shrimp, Penaeus duorarum Burkenroad. Bull mar Sci 24:606-627

Orsi Relini L, Semeria M (1983) Oogenesis and reproductive strategies in bathyal penaeid prawns, Aristeus antennatus and Arıstaeomorpha foliacea. Rapp P-v Reun Comm int Mer Médit 28:1-2

Penn JW (1980) Spawning and fecundity of the western king prawn, Penaeus latisulcatus Kishinovye, in Western Australian waters. Aust J mar Freshwat Res 31:21-35

Pérez Farfante, I (1969) Western Atlantic shrimps of the genus Penaeus. Fish Bull US 67:461-591

Pérez Farfante I (1987) Revision of the gamba prawn genus Pseudaristeus, with description of two new species (Crustacea: Decapoda: Penaeoidea). Fish Bull US 85:311-338

Ribeiro Cascalho A, Arrobas 1 (1987) Observations on the biology of Parapenaeus longirostris (Lucas, 1846) from the south coast of Portugal. Invest Pesq 51(Supl 1):201-212

Sardà F, Cros ML, Sesé B (1989) Ca balance during moulting in the prawn Aristeus antennatus (Risso, 1816): the role of cuticle calcification in the life cycle of decapod crustaceans. J exp mar Biol Ecol 129:161-171

Sardà F, Demestre M (1985) Determination of the intermoult stages in Aristeus antennatus (Risso, 1816) by setal development. Rapp P-v Réun Comm int Mer Médit 29: 305-307 
Sastry AN (1983) Ecological aspects of reproduction. In: Vernberg FJ, Vernberg WB (eds) The biology of Crustacea, Vol 8, Environmental adaptations. Academic Press, New York, p 179-270

Scheer BT (1960) Aspects of the intermoult cycle in natantians. Comp Biochem Physiol 1:3-18

Shlagman A, Lewinsohn C, Tom M (1986) Aspects of the reproductive activity of Penaeus semisulcatus De Haan along the south eastern coast of the Mediterranean. PSZN

This article was submitted to the editor
I: Mar Ecol 7:15-22

Skinner DM (1985) Molting and regeneration. In: Bliss DE. Mantel LH (eds) The biology of Crustacea. Academic Press, New York, p 43-146

Webster SG (1982) Seasonal anecdysis and moulting synchrony in field populations of Palaemon elegans (Rathke). Estuar coast Shelf Sci 15:85-94

Yano I (1988) Oocyte development in the kuruma prawn Penaeus japonicus. Mar Biol 99:547-553

Manuscript first received: November 7, 1994 Revised version accepted: May 11, 1995 